Uluslararası Yönetim İktisat ve Işsetme Dergisi, ICAFR 16 Özel Saylsı

Int. Journal of Management Economics and Business, ICAFR 16 Special Issue

\title{
RELATION OF 3PL AND 4PL ACTIVIES AND THEIR EFFECT ON EMERGING ECONOMIES
}

\author{
Arş. Görv. Ceyda AKTAN, \\ Türk Hava Kurumu Üniversitesi \\ caktan@thk.edu.tr \\ Öğr. Görv. Eyyüp Ensari ŞAHİN \\ Hitit Üniversitesi \\ eyupensarisahin@hitit.edu.tr \\ Öğr. Görv. Nizamettin BAŞARAN \\ Niğde Üniversitesi \\ nbasaran@nigde.edu.tr
}

\begin{abstract}
There are constant developments in logistics chains around the World. For a competitive advantage over their rivals, businesses need to utilize their core competencies and start to outsource to lower costs, provide higher quality and efficient timing to meet their customers' needs. Therefore the principle of third and fourth party logistics have been introduced. These systems have great impact on economies especially to emerging ones. Using a literture review methodology, the aim of this study is to show the relationship between the concepts of $3 P L$ and $4 P L$, explain how these concepts altogether effect the business environment in emerging economies.
\end{abstract}

Key Words: Third Party Logistics, Fourth Party Logistics, Emerging Economies,

\section{Introduction}

There are constant developments in logistics chains around the World due to an increase in the need to efficiently facilitate movement of materials and goods between borders. In order to achieve a competitive advantage over their rivals, businesses need to utilize their own core competencies and also start to outsource the rest to establish and maintain lower costs, higher quality and efficient timing to meet their customers' needs. Therefore the principle of third party logistics has become an important and a necessary concept for businesses in recent years (Mentzer et al., 2004:16). However, already, newer terms such as fourth party logistics and fifth party logistics have been introduced as an extention to the third party logistics concept (Hosie et al., 2007:10). These concepts do link to one another but there is still alot that needs to be assessed and researched regarding their effects, espectially on emerging economies. Why especially emerging economies? Because in emerging economies there is cheap labour, natural resources that cannot otherwise be exploited, and a great need for foreign investment for economic growth. Establishing 3PL and 4PL businesses in these countries can result in cost efficienciency and greater competitive advantage for businesses as well as provide economic prosperity to these countries (Wagner and Sutter, 2012:244). Using a literture review methoology, the aim of this study is to show the relationship between the concepts of 3PL and 4PL, explain how these concepts altogether effect the business environment in emerging economies and lastly to point out if there are any differences between developed countries 


\section{Uluslararası Yönetim İktisat ve İsletme Dergisi, ICAFR 16 Özel Sayısı Int. Journal of Management Economics and Business, ICAFR 16 Special Issue}

and the emerging economies in terms of these effects. The basic purpose of this research is also to point out the gap that exist within the area. Although the concepts of third party logistics and fourth party logistics is known as well as what emerging economies are and their position regarding outsourcing, the concept of third and fourth party logistics have not been researched against emerging economies. It is proposed that this topic is a vital and this gap needs to be filled as quickly as possible through quantitative research.

\section{Research Method}

To be able to show the connection between the elements: third party logistics, fourth party logistics, their effects on emerging economies and to be able to find support for the connection, previous research needed to be analyzed. Therefore, first of all, to narrow the results into a workable number of articles, in this study, search engines were used to search the databases such as Google Scholar, EmeraldInsight and ScienceDirect to add to the article pool. During the search, keywords such as; "third party logistics", "fourth party logistics", "emerging economies", "effect of 3PL" and "3PL and 4PL" were used to further narrow the results. This step was taken in order to identify the articles written within these topics which were not among the ones identified previously.

After identifying the appropriate journals, a content analysis methodology was used to review the literature. Using this method helps researchers in identifying and sorting the literature under various categories (Pokharel and Mutha, 2009:167). The reason for using such an analysis for this study was to put forward the number of articles published in the recent years on the topics of 3PL, 4PL and their effect on emerging economies, and to see which areas they coincided. What else that was important was to analyze the journals to see whether such a study was conducted previously and what sort of results they came up with.

During the literature search there were few delimitations of the search for narrowing the results;

- In the literature review only the last few years were taken into account as these topics are still relatively new topics. Research shows that the issue of outsourcing, third party logistics and the supply chain management started showing in jounals from the year 1990 onwards and the inclusion of the fourth party logistics activities after the 2000s. Therefore, a more current body of literature needed to be looked into in order for all the elements to be found together.

- $\quad$ The issue of third party logistics come up in different headings such as outsourcing logistics activities or shorter versions like 3PL or 4PL. Therefore only ones where terms "third party logistics", "3PL" , "fourth party logistics", "4PL" and "outsourcing" used in headings or keywords were taken into account.

- $\quad$ For relation to emerging economies, articles with terms "emerging economies" and "developing countries" in the heading or the keywords section were taken into account.

The study then continued with a summary of the findings from the analysis and short descriptions of each of the researched elements: third party logistics, fourth party logistics and their effects on the emerging economies. How these elements link together and how future research can shape the area will be discussed at the end.

\section{Results}




\section{Uluslararası Yönetim İktisat ve Işsetme Dergisi, ICAFR 16 Özel Saylsı \\ Int. Journal of Management Economics and Business, ICAFR 16 Special Issue}

\subsection{Emerging Third Party And Fourth Party Logistics Activities}

Until the years upto 1990's firms had been conducting every possible process within their own systems and were not looking at outsourcing as a favorable strategy. Firms under the effect of globalization and the rapid technological developments needed to change the way that they were previously operating and adapt to these changes. These firms started to include professional services or even people within their structures to adapt to changing competitive conditions of our times, to increase firm value and the importance of the firm. In simple word, they needed external professional support for survival. By doing this, firms can cut down capital investments that they will be making to their logistics activities and at the same time they can focus on their own core competencies. In addition, they will have the opportunity to meet their customers' needs and wants, which are the reason for their existence. Logistics expenditures will also start to decrease (Hong et al., 2004: 18). In literature this process is referred to as "outsourcing".

Outsourcing has many different definitions in literature. In two words outsourcing can be expressed as - Contracting Out (Kakabadse and Kakabadse, 2002:190). Leeman and Reynolds (2012) define outsourcing as "the utilization by a firm of outside companies to perform duties that have typically been performed internally" which focuses on the transfer of control to others and it is supported by the definition given by Donada and Nogatchewsky (2009:368) "outsourcing is the transfer of control of an activity to a supplier" (Leeman and Reynolds, 2012:601, Donada and Nogatchewsky, 2009:368). Another definition is that outsourcing is the process for firms to transfer its firm operations together with its related assets to third party companies in order to benefit from one or more of the following objectives; focus more on their core activities, reduce their costs, convert their fixed costs into variable ones, to benefit from the related suppliers investment and creativity strength and to increase the speed of access to the market. All of these listed activities are conducted by third party logistics firms.

Third party logistics providers are firms that undertake the customer's activities in the logistics field especially being transportation and storage. These firms who have the necessary facilities, equipment and staff and have specialized in this area, take on themselves the complete chain's design and management. The chain includes activities such as international transportation, storage, stock control, packaging, labelling, shipping, distribution and similar activities. It could be seen that there are a lot of aspects attached to third party logistics processes (Yeung et al., 2006:211). Some of these providers can successfully implement strategies to coordinate and organize these processes but there are too much to take on for a single provider. Hence this burden on third party logistics providers and their incapacity to respond adequately to these needs to led to the introduction of a new concept: fourth party logistics (4PL) (Hosie et al., 2007:10).

Fourth party logistics firms started being seen after the 90's within the logistics industry as third party logistics firms started becoming more and more inadequate. Third party logistics firms generally concentrated on certain specific areas such as transportation and storage and lost their ability to respond to the complex logistics needs of companies and organizations (Hosie et al., 2007:10). Therefore to fill this need, fourth party logistics providers were introduced that gives professional service on solving complex logiistics chains problems. Actually, when third and fourth party logistics 


\section{Uluslararası Yönetim İktisat ve İsletme Dergisi, ICAFR 16 Özel Sayısı Int. Journal of Management Economics and Business, ICAFR 16 Special Issue}

services are compared it could be clearly seen that third party logistics concentrate on implementation and enforcement issues whereas fourth party logistics managers and consultants concentrate on strategic and technology supported issues (Vasiliauskas and Jakubauskas, 2007:68). A detailed definition of third party logistics and fourth party logistics is given in the following section.

\subsection{Definition Of Third Party And Fourth Party Logistics}

In previous sections a brief introduction to the topic was given together with the definition and use of outsourcing. An explanation of what third party logistics does, how it has evolved into the introduction of fourth party logistics was given. However, these terms also need to be clearly explained in order to be able to relate them to each other and to how they contribute to emerging economies.

Third party logistics can be defined as having to outsource the logistics activities a firm does where it was previously performed in-house from a third source (Lieb and Randall, 1996:305). It is considered to be the orchestrator of the logistics chain and usually shows in literature with three different theories; Transaction Cost Economies, Resource-Based Theory and Network Theory (Zacharia et al., 2011:41). To be able to understand the term "three/third" found within the name, concepts of first and second party needs also to be known;

First Party: Manufacturer, wholesaler, retailer or consignor,

Second Party: a business who is a direct customer (supplier) of the first party,

Third Party: Freight forwarders, service providers, carriers, warehouse operators and so on,

Fourth Party: businesses who integrate and coordinate logistics products and information flow processes.

Fourth party logistics providers acts as a "chain integrator" and is established to deal with the relationships that exist between the supplier, customer and the third party logistics provider and also has the effect of reducing transaction costs (Bourlakis and Bourlakis, 2005:94). The concept and contents of 4PL was first defined by Accenture firm who still holds the trades mark for it (Hosie et al., 2007:9).

\subsection{Contributions Of Third Party And Fourth Party Logistics Activities To Emerging Economies}

In order to discuss the effects of third and fourth party logistics on emerging economies, a definition of what it is meant by countries with emerging economies needs to be made clear. Although there are numerous definitions of emerging economies, this study narrows these definitions to a single one. According to Hoskisson et al. (2000), the definition of emerging economies must have two components that must be satisfied. These components are firstly is that particular country must have a really fast and rapid economic development and secondly, the governments of these countries must make policies in favour of liberalization and towards adopting a free market system. 51 countries were identified by the International Finance Corporation as countries with emerging economies in 1999 (Hoskisson et al., 2000:249). However, it has been 17 years since and this number would have slightly changed. 


\section{Uluslararası Yönetim İktisat ve İsletme Dergisi, ICAFR 16 Özel Sayısı Int. Journal of Management Economics and Business, ICAFR 16 Special Issue}

In this section of the research, the identified emerging economies and their use of outsourcing will be explained both in the context of these countries outsourcing from others and also from the developed countries outsourcing from these emerging economies. These will then be linked to third and fourth party logistics providers and how these activities contribute to these countries.

In the previous sections it was discussed that outsourcing now became an important strategy for firms to overcome the pressure applied through globalization and the need to be more productive and profitable. This strategy can be applied to both countries with developing economies or developed countries. Outsourcing strategy is an important activity for firms located in emerging economies as it is now vital for their corporate transformation (Javalgi et al., 2009:156). However, what may differ between the two might be that the products and services they offer during the exchange that completes any transaction. Emerging economies can provide low-cost labour services for improving margins (Wagner and Sutter, 2012:244) as well as big amounts of the needed natural resources whereas developed cuntries can contribute more with their Intellectual Capital and skilled labour, especially for management positions.

Outsourcing is used by emerging economies to obtain the services and products that are not part of their core competencies. These outsourcing activities can be either from their own countries or it could be from outside their borders, which is referred to as "offshore outsourcing" (Carmel and Agarwal, 2002:65). Outsourcing can provide many benefits to these countries such as provide them with a chance to obtain skilled labour to overcome their skills shortages or it could be to obtain the technology that they could not otherwise buy or establish within their own premises to provide the products and services which other countries export from them. Considering that many countries actually need the resources that developing countries or in other words, the countries with emerging economies have, such as, cheap labour, natural resources, their core competencies. They need to make investments to these countries. Companies within these emerging economies will need support in areas of strategy, knowledge, Intellectual capital in order to utilize these core competencies. Therefore, outsourcing gives an opportunity for emerging economies to obtain the necessary skills to make the most of their own core competencies.

These countries which have been identified as emerging economies are particular important when it comes to international trade and relations. Although they offer many advantages such as the cheap labour and resources, they also have disadvantages for companies. Both the domestic and foreign firms and investors faces uncertainties, risks associated with instability within these countries. Lack of set standards and a legal frameworks, these countries are perfect target for opportunism, bribery and corruption. There needs to be more effective corporate governance structures as it is usually slow and difficult in emerging economies (Hoskisson et al., 2000:249, Nelson et al., 1998:27).

In terms of third party logistics and fourth party logistics providers similar conditions exist as outsourcing strategies. As these third and fourth party logistics providers are performing outsourcing functions, they provide countries with emerging economies the intermediary they require with the necessary skills and information, they are referred to as the "middle men" (Sheffi, 1990:27). being the suppliers of natural resources and sheap labour, emerging economies become the important part of the supply 


\section{Uluslararası Yönetim İktisat ve Işsetme Dergisi, ICAFR 16 Özel Saylsı Int. Journal of Management Economics and Business, ICAFR 16 Special Issue}

chain network. They need to make sure that their sources successfully are transferred to the company requiring these and at this point the third and fourth party logistics providers come into question. They can improve overall performance, make sure these countries can enter into newer markets, find global solutions to their sales problems and as one of the most important contributions, improve the economic progress of the country. 3PL and 4PL providers adds value to supply chain activities and enhance the economic growth of emerging economies (Bask, 2001:472).

To support the third and fourth party logistics activities around the World, recently, as technology becomes more complex and easier to use, costs relating to shipping of goods and materials becomes lower. However at this situation more research needs to be conducted to first see if these activities involve trade between developed countries and emerging economies or if they are from one emerging country to the other. Most studies show that although this technological developments reduced logistics costs for developed countries, they have not affected the countries with emerging economies such as China and India. This is highly related to the modes of transport. Although in recent times the cost of air transport have decreased, costs relating to sea/ocean transportation have not showed the same reduction. It is the sea/ocean transport which is the widely used mode of transport for most emerging economy trade and hence part of the 3PL and 4PL structure (Hanson, 2012:5).

Another factor that needs to be considered regarding third and fourth party logistics providers is that they need to form strong relationships between the supply chain members which can also be referred to as their customers (Tian et al., 2010:359). It is shown in previous research that stronger ties/relationship between the parties lead to more successful operation of the network (Hofer et al., 2009:141). When it comes to these providers and the inclusion of emerging economies, it must be taken ito account the different cultural, institutional environment that exists. These 3PL and 4PL providers must collect information about the institutional differences when in business with companies within these countries. Institutional environment refers to the formal environment (legal rules) and the informal environment (norms, culture, etc.) (Meyer et al., 2009:63).

\section{Conclusion}

This study was conducted to basically reveal the gap that exists within the area of logistics on the third and fourth party logistics providers and their contributions on the emerging economies. Changing conditions around the world has led the way to the introduction of a more complex networks in logistics. This has led the companies to make most of what they already have and begin to outsource what they do not. Complex logistics networks were among the concepts that became too much for a company to perform in-house, they started being outsourced. A new business opportunity had came about. Third party logistics providers took on the job of performing these logistics activities the firm did previously in-house. As time passed workload became even more and even the third party logistics providers were not able to complete all the required tasks by themselves and fourth party logistics providers were born. They brought together with them advantages and disadvantages to the economies of countries as explained in previous sections.. 


\section{Uluslararası Yönetim İktisat ve İsletme Dergisi, ICAFR 16 Özel Sayısı Int. Journal of Management Economics and Business, ICAFR 16 Special Issue}

In this study all of these three issues were briefly explained and the connection between them were shown. From the literature review on the identified journal articles, it was seen that there were some articles relating to the issues individually or in pairs, but there were no study identified involving all three issues together. Considering the importance and the link between third party logistics, fourth party logistics and their effects on emerging economies, it can be identified as a major gap in the business field. Research needs to be conducted to fill this gap.

\section{References}

Anu H. Bask. (2001). Relationships among TPL providers and members of supply chains - a strategic perspective. Journal of Business \& Industrial Marketing, Vol. 16 Iss 6 pp. $470-486$.

Bourlakis, C. and Bourlakis. M. (2005). Information technology safeguards, logistics asset specificity and 4th party logistics network creation in the food retail chain. Journal of Business and Industrial Marketing, Vol. 20, No. 2/3, pp. 88-98.

Carmel, E., \& Agarwal, R. (2006). The maturation of offshore sourcing of information technology work. In Information systems outsourcing, Springer Berlin Heidelberg. pp. 631-650.

Donada, C. Nogatchewsky, G. (2009). Emotions in outsourcing. an empirical study in the hotel industry. International Journal of Hospitality Management, 28, (2009), $367-$ 373.

Hanson G. H. (2012). The rise of middle kingdoms: emerging economies in global trade. National Bureau Of Economic Research, Nber Working Paper No. 17961, Jel No. F10 pp.1-35.

Hong, J., Chin, Anthony T.H., Liu, B. (2004). Logistics outsourcing by manufacturers in china: a survey of the industry. Transportation Journal, Vol.18, pp.17-25.

Hoskisson, R. E., Eden, L., Lau, C. M., \& Wright, M. (2000). Strategy in emerging economies. Academy of Management Journal, 43(3), 249-267.

Hosie, P. and Egan, Victor \& Li, Y. (2007). Drivers of fifth party logistics (5pl) service providers for supply chain management. Journal Of Business Logistics, Vol 11, No.Z 199027 pp.27-39.

Hofer, A. R., Knemeyer, A. M, Dresner, M.E. (2009). Antecedents and dimensions df customer partnering behavior in logistics outsourcing relationships. Journal of Business Logistics, Vol. 30, No. 2, pp.141-159.

John T. Mentzer S. L. Michelle B., (2004). Toward a unified theory of logistics, International Journal of Physical Distribution \& Logistics Management, Vol. 34 Iss 8 pp. $606-627$.

Kakabadse A. , Kakabadse N. (2002). Trends in outsourcing: contrasting USA and Europe, European Management Journal, Vol. 20, No. 2, pp. 189-198, April. 
Uluslararası Yönetim İktisat ve İşletme Dergisi, ICAFR 16 Özel Sayısı Int. Journal of Management Economics and Business, ICAFR 16 Special Issue

Leeman, D., \& Reynolds, D. (2012). Trust and outsourcing: do perceptions of trust influence the retention of outsourcing providers in the hospitality industry? International Journal of Hospitality Management, 31(2), pp.601-608.

Lieb, R. and Randall, H. (1996) A comparison of the use of third party logistics services by large American manfacturers, 1991, 1994, and 1996. Journal of Business Logistics, No:1 pp. 17.

Meyer KE, Peng MW, Estirn, S. \&Bhaumik, S.K.. (2009). Institutions, Resources and entry strategies in emerging economies, Strategic Management Journal Strat. Mgmt. J., 30: 61-80.

Nelson, J.M., Tilley, C., and Walker, L. (Eds.). 1998. Transforming post-communist political economies; Task force on economies in transition, National Research Council. Washington, DC: National Academy Press.

Pokharel S., Mutha A. 2009. Perspectives in reverse logistics: a review. Resources, Conservation and Recycling, Vol. 53, No. 4, pp. 175-182.

Rajshekhar (Raj) G. Javalgi, Ashutosh Dixit, Robert F. Scherer, (2009). Outsourcing to emerging markets: Theoretical perspectives and policy implications, Journal of International Management No: 15, pp. 156-168.

Sbeffi, Y. (1990). Third party logistics: Present and future prospects. Journal of Business Logistics, VoL 11, No.Z 199027 pp.27-39

Yeung J., Hoi Y., Willem S., Chee-Chuong S., Baofeng H.(2006). International Journal of Physical Distribution \& Logistics Management, Vol. 36 No. 3, 2 pp. 210-230.

Wagner, M., Sutter, R..(2012). A qualitative investigation of innovation between thirdparty logistics providers and customers. Int. J. Production Economics 140, pp. 944-958.

Vasiliauskas A., Jakubauskas. G.(2007). Principle and benefits of third party logistics approach when managing logistics supply chain, Transport, Vol XXII, No 2, 6872 .

Zacharia, Z., Nada R. Sanders1 A.,\& Nancy W. N.(2011). The Emerging role of the thirdparty logistics provider (3PL) asan orchestrator, Journal of Business Logistics, 32(1): 40-54.

http://lojistikmakaleleri.blogspot.com.tr/2014/03/3pl-ucuncu-parti-lojistik-nedir.html Erişim tarihi: 09.03.2016. 